First publ. in: Protoplasma 189 (1995), 1-2 pp. 61-72

\title{
The infection process of Fusarium oxysporum in cotton root tips
}

\author{
E. Rodríguez-Gálvez and K. Mendgen* \\ Lehrstuhl für Phytopathologie, Fakultät für Biologie, Universität Konstanz, Konstanz \\ Received January 16, 1995 \\ Accepted March 20, 1995
}

Summary. Conidia of Fusarium oxysporum f, sp. vasinfectum started to germinate on the roots of cotton (Gossypium barbadense $\mathrm{L}$.) $6 \mathrm{~h}$ after inoculation and formed a compact mycelium covering the root surface. $18 \mathrm{~h}$ later, penetration hyphae branched off and infected the root. The number of penetration hyphae increased with the number of conidia used for inoculation. The optimal temperature for penetration was between 28 and $30^{\circ} \mathrm{C}$. The highest numbers of penetration hyphae were found in the meristematic zone, 40 percent less in the elongation and root hair zones, and none in the lateral root zone. The fine structure of the infection process was studied in protodermal cells of the meristematic zone and in rhizodermal cells of the elongation zone. The penetration hyphae were well preserved after freeze substitution and showed a Golgi equivalent consisting of three populations of smooth cisternae. Plant reactions were found already during fungal growth on the root surface. In the meristematic zone, a thickening of the plant cell wall due to an apposition of dark and lightly staining material below the hyphae occurred. This wall apposition increased in size around the hypha invading the plant cell and led to the formation of a prominent wall apposition with finger-like projections into the host cytoplasm. In the elongation zone, the deposits around the penetration hypha appeared less thick and the dark inclusions were less pronounced. High pressure freezing of infected cells revealed, that $F$. oxysporum penetrates and grows within the host cells without inducing damages such as plasmolysis, cell degeneration or even host necrosis. We suggest that $F$. oxysporum has an endophytic or biotrophic phase during colonization of the root tips.

Keywords: Fusarium oxysporum; Cotton roots; Penetration hyphac; Golgi equivalent; Cell wall apposition; High pressure freezing.

Abbreviation: $\mathrm{Ph}$ penetration hyphae.

\section{Introduction}

Fusarium oxysporum is a plant pathogen with worldwide distribution. It causes wilting of many host

* Correspondence and reprints: Phytopathologie, Fakultät für Biologie, Universität Konstanz, Universitätsstrasse 10, D-78434 Konstanz, Federal Republic of Germany. plants, 75 formae specialis are pathogenic on different hosts (Armstrong and Armstrong 1981). Most studies of the interaction between $F$. oxysporum and its host plants have concentrated on the "secondary determinative phase" which is defined by colonization and establishment of the fungus in the vascular bundles (Beckman 1987). For this phase the physical and chemical factors, which might influence the resistance of the plant against the pathogen, have been investigated (Beckman 1987). The "primary determinative phase" including penetration of the fungus through the rhizodermis into the root and the ensueing colonization of cortex and endodermis up to the vascular system, has been studied only rarely. There are no quantitative data available indicating in which root zone penetration occurs. Alconero (1968) observed penetration of $F$. oxysporum $\mathrm{f}$. sp. vanillae in the root cap zone. Farquhar and Peterson (1989) found penetration of $F$. oxysporum f. sp. pini within the meristematic zone, and Bhalla et al. (1992) within the elongation zone of the root. In this work we quantified the number of penetration hyphae of $F$. oxysporum in each zone of the cotton root.

A clear picture of host cell reactions is also missing. Most authors mentioned plasmolysis (Bhalla et al. 1992, Brammall and Higgins 1984) and cell death (Charest et al. 1985, Farquhar and Peterson 1985) but also the deposition of wall appositions (Bishop and Cooper 1983, Jordan et al. 1987). These results were obtained after chemical fixation. Recently it was shown that after high pressure freezing in combination with freeze substitution, organelles, membranes and the cytoskeleton of root tips are much better pre- 
served (Kiss et al. 1990). This was also shown for the host-parasite interface after rust infection of leaves (Knauf et al. 1989). Therefore we used this technology to study the early events during infection of cotton root tips by F. oxysporum.

\section{Material and methods}

Plant material

Cotton seeds (Gossypium barbadense L. cv. Pima) were disinfected for 5 min with $6.5 \%$ sodium hypochlorite and then rinsed with sterile water for about $1 \mathrm{~h}$. For germination, the cotton seeds were placed in a glass petri dish $\left(15 \mathrm{~cm}\right.$ diameter) with wet filter paper at $28^{\circ} \mathrm{C}$ in darkness for 2 days.

\section{Fungus isolate}

Fusarium oxysporum Schlecht f. sp. vasinfectum (Atk) Snyd. and Hans., was isolated in Peru (Departamento de Sanidad Vegetal, Universidad Nacional de Piura). It was repeatedly reisolated from cotton plants with wilting symptoms and cultured on potato-dextrose-agar $(\mathrm{pH} 7)$ at $28^{\circ} \mathrm{C}$.

\section{Inoculum}

Microconidia were obtained by filtration of a conidial suspension through cotton wool. The filtrate was centrifuged for $10 \mathrm{~min}$ at $150 \mathrm{~g}$. The supernatant was discarded and the mitochondria resuspended in distilled water. This procedure was repeated three times. $10 \mu \mathrm{l}$ drops with $10^{6}-10^{7}$ microconidia/ml were spread on $1 \mathrm{~mm}$ thick layers of water-agar (3\%) in a petri dish. Agar pieces were cut out with a cork borer ( $1 \mathrm{~mm}$ diameter) and used for inoculation. The number of conidia on the agar surface was determined with a light microscope ( $\times 40$ lens $)$.

\section{Inoculation}

Two days after seed germination, the agar pieces were placed on the root surface with the spores facing the root. The influence of the temperature on fungal penetration was studied with 7 roots per treatment, inoculated in the elongation zone with $1211 \pm 53 \mathrm{conidia} / \mathrm{mm}^{2}$. The effect of the root zone on fungal penetration was studied with 6 roots per treatment, inoculated with $530 \pm 36 \mathrm{conidia} / \mathrm{mm}^{2}$ at $28^{\circ} \mathrm{C}$. The effect of conidia concentration was studied with 7 roots per treatment, inoculated in the elongation zone at $28^{\circ} \mathrm{C}$.

\section{Light microscopy}

Fixation

$24 \mathrm{~h}$ after inoculation root pieces ( $2 \mathrm{~mm}$ long) were cut out and fixed in a solution of $2 \%$ glutaraldehyde in $0.05 \mathrm{M}$ potassium phosphate

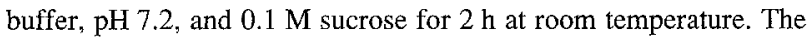
samples were rinsed in the same buffer 3 times for $15 \mathrm{~min}$ and postfixed in $1 \%$ osmium tetroxide in the same buffer for $1 \mathrm{~h}$ at $4{ }^{\circ} \mathrm{C}$. After a wash in buffer, samples were dehydrated in increasing acetone concentrations $(20,40,60,80 \%$, and three times in $100 \%)$ for $15 \mathrm{~min}$ each. Then they were embedded in Epon/Araldite (Welter et al. 1988).

\section{Quantification of the fungal penetration}

The number of fungal infection structures was counted in 40 serial cross sections, $5 \mu \mathrm{m}$ thick. In each section, $0.5 \mathrm{~mm}$ of the root sur- face was studied. Thus, a surface of $0.1 \mathrm{~mm}^{2}$ of the root was evaluated. Each experiment was repeated 6-7 times.

\section{Statistical analysis}

For the analysis of the results the statistical program Statistica/Mac (StatSoft, Inc.) was used. Due to the heterogeneity of the variances, the non-parametric test-system of Kruskal Wallis Anova was used for the variance analysis. For the comparison of the treatments the Mann-Whitney-U-test was utilized.

Electron microscopy, high-pressure freezing and freeze-substitution $24 \mathrm{~h}$ after inoculation, roots were infiltrated with $8 \%(\mathrm{v} / \mathrm{v})$ methanol and immediately placed into aluminum cups, $2 \mathrm{~mm}$ in diameter, $0.2 \mathrm{~mm}$ deep, and frozen in a Balzers HPM 010 (Balzers Union, Liechtenstein) high-pressure freezing machine (Mendgen et al. 1990). Samples were freeze substituted with $2 \%$ osmium tetroxide in acetone in three stages: $24 \mathrm{~h}$ at $-90^{\circ} \mathrm{C}, 12 \mathrm{~h}$ at $-60^{\circ} \mathrm{C}$, and $9 \mathrm{~h}$ at -30 ${ }^{\circ} \mathrm{C}$. After substitution the temperature was raised to $0^{\circ} \mathrm{C}$ and the samples were rinsed 3 times for 15 min with acetone.

Sections were produced with a Reichert-Jung Ultracut $\mathrm{E}$ microtome and stained with a mixture of calcium permanganate $\left(0.8 \% \mathrm{KMnO}_{4}\right.$ in $0.1 \mathrm{M}$ calcium phosphate buffer $\mathrm{pH} 5.2$ ) and uranyl acetate ( $3 \%$ in water) in a ratio of $1 / 120$ (Hayat 1975) for $12 \mathrm{~min}$. Sections were examined in a Zeiss EM $10 \mathrm{CR}$ electron microscope operating at $60 \mathrm{kV}$.

\section{Results}

\section{Light microscopy}

\section{Colonization of the root surface}

Conidia of Fusarium oxysporum f. sp. vasinfectum germinated $6 \mathrm{~h}$ after inoculation. The germ tubes did not penetrate the root but colonized the root surface and produced a dense net-like mycelium (data not shown). Hyphae grew irregularly, or along the anticlinal cell walls. $24 \mathrm{~h}$ after inoculation, the fungus started to penetrate: surface hyphae produced branches,

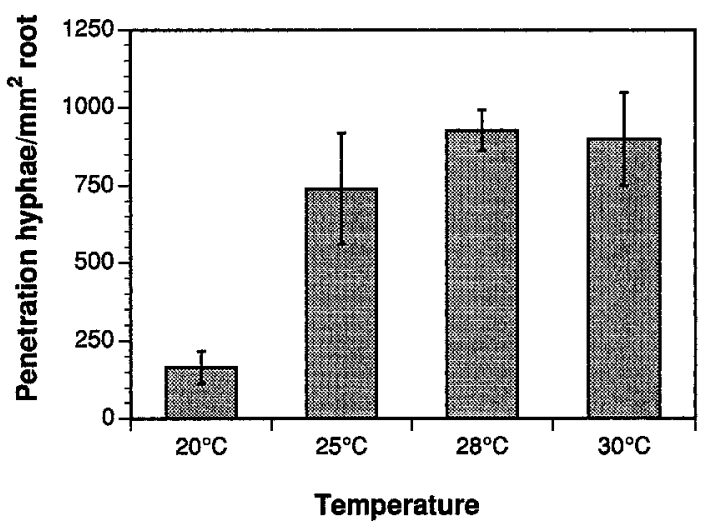

Fig. 1. Influence of temperature on the number of penetration hyphae of $F$. oxysporum. Inoculation was performed with $1211 \pm 53$ conid$\mathrm{ia} / \mathrm{mm}^{2}$ in the elongation zone of cotton roots 


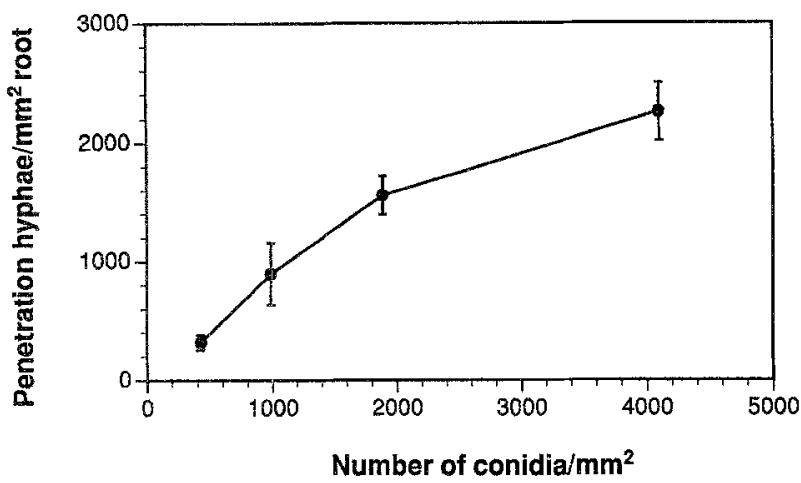

Fig. 2. Influence of inoculum concentration on the penetration frequency of $F$. oxysporum. Inoculation was performed in the elongation zone of cotton roots at $28^{\circ} \mathrm{C}$. The values were statistically different from each other $(\mathrm{p}<0.05)$

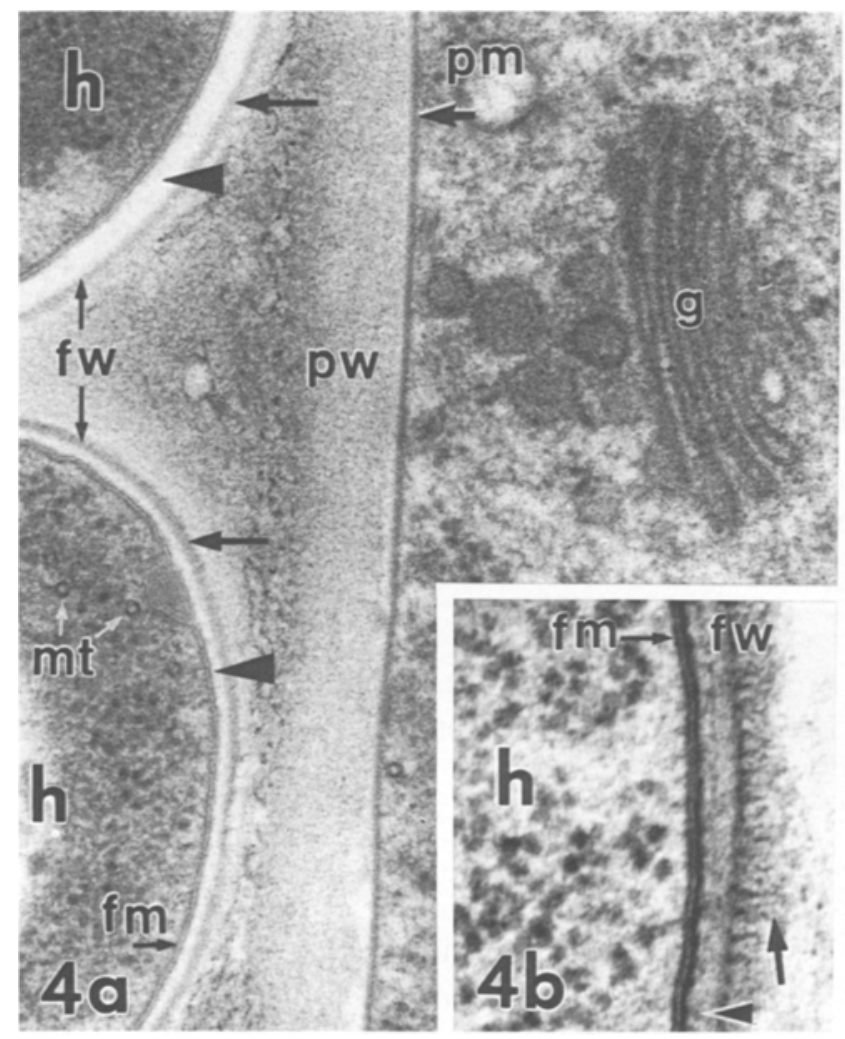

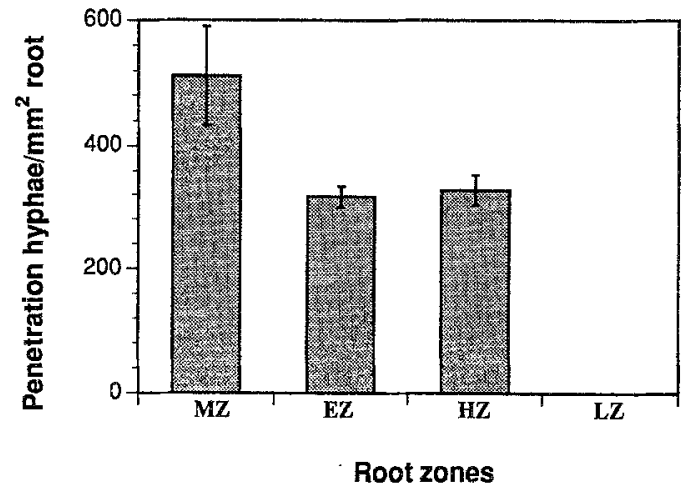

Fig. 3. Efficiency of fungal infection in different root zones. Inoculation was performed with $530 \pm 29$ conidia/mm $/ \mathrm{mm}^{2}$ at $28^{\circ} \mathrm{C}$. MZ Meristematic zone, $E Z$ elongation zone, $H Z$ root hair zone, $L Z$ lateral roots zone

Fig. 4a, b. The wall of Fusarium hyphae showing a fibrillar layer (arrows) and a translucent layer (arrowheads). $\times 75,000$ and $\times 120,000$, respectively, $f m$ Fungal plasma membrane, $f w$ fungal cell wall, $g$ Golgi apparatus, $h$ hypha, $m t$ microtubule, $p m$ plant plasma membrane, $p w$ plant cell wall

Fig. 5. Three types of smooth cisternae belonging to the Golgi equivalent in a penetration hypha of $F$. oxysporum. A Cisternae 56 nm wide, $B$ cisternae $40 \mathrm{~nm}$ wide, $C$ cisternae $30 \mathrm{~nm}$ wide. $\times 75,000$. er Endoplasmic reticulum, $m$ mitochondrion

which immediately penetrated the root inter- or intracellularly. These branches or penetration hyphae $(\mathrm{Ph})$ (Bishop and Cooper 1983) were characterized by a reduced diameter compared to the mycelium forming hyphae $(1.42 \pm 0.08 \mu \mathrm{m}$ vs. $2.19 \pm 0.13 \mu \mathrm{m})$.

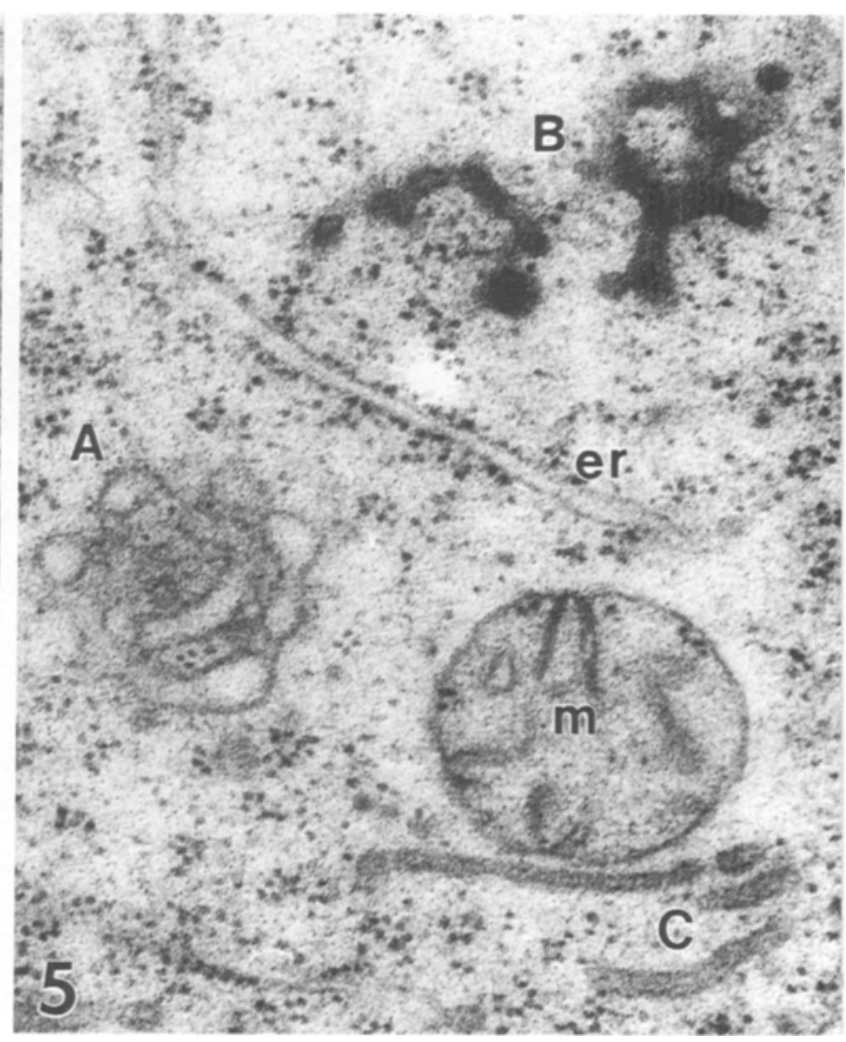




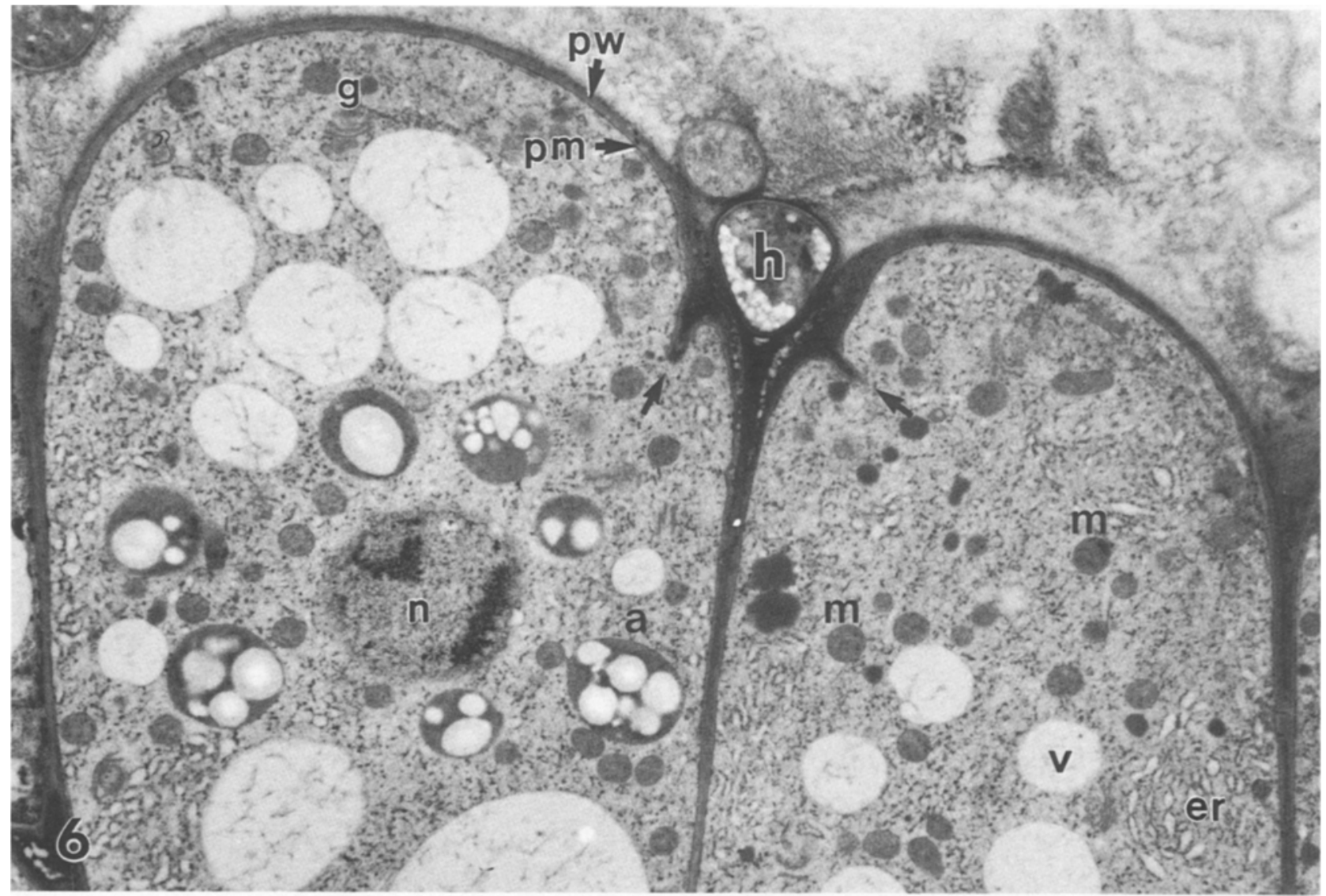

Fig. 6. Transversal section of protodermal cotton cells in the meristematic root zone. A hypha is growing over the anticlinal cell wall. The plant cells have produced wall appositions (arrows) below the hypha. a Amyloplast, $e r$ endoplasmic reticulum, $g$ Golgi apparatus, $h$ hypha, $m$ mitochondrion, $n$ nucleus, $p m$ plant plasma membrane, $p w$ plant cell wall, $v$ vacuole. $\times 7,340$

ber of penetration hyphae was produced at $28{ }^{\circ} \mathrm{C}$ and $30{ }^{\circ} \mathrm{C}\left(927\right.$ and $899 \mathrm{Ph} / \mathrm{mm}^{2}$ root, respectively). Considerably lower numbers were found at $20^{\circ} \mathrm{C}$ $(\mathrm{p}<0.05)$.

The density of the penetration hyphae was positively correlated with the number of conidia used for inoculation (Fig. 2). Most penetration hyphae (2261 $\mathrm{Ph} / \mathrm{mm}^{2}$ root) were produced after inoculation with $4100 \pm 246$ conidia $/ \mathrm{mm}^{2}$. The best conditions for the development of penetration hyphae occurred in the meristematic zone (Fig. 3). Nearly $40 \%$ less penetration hyphae were formed in the elongation and root hair zone $(p<0.05)$. No penetration of the fungus was found in the lateral root zone.

\section{Electron microscopy}

\section{Meristematic zone}

Fungal fine structure: The fungal wall consisted of a lightly staining layer and an outer, fibrillar layer (Fig, 4 a, b). In the cytoplasm, we observed nuclei, mitochondria, endoplasmic reticulum and a well developed Golgi equivalent. The Golgi equivalent consisted of three populations of smooth cisternae

Figs. 7-10. The meristematic zone infected with $F$. oxysporum. a Amyloplast, $f m$ fungal plasma membrane, $f w$ fungal cell wall, $g$ Golgi apparatus, $g e$ Golgi equivalent, $h$ hypha, $m$ mitochondrion, $p m$ plant plasma membrane, $p w$ plant cell wall, $v$ vacuole, wa wall appositions

Fig. 7. Hypha over the anticlinal cell wall and wall appositions with finger-like projections into the host cell (arrows). $\times 25,000$

Fig. 8. Intercellular penetration of the fungus. Cell wall appositions surround the hypha. $\times 18,900$

Fig. 9. Intracellular penetration of the fungus with wall appositions along the penetration hypha. $\times 17,500$

Fig. 10. Overview of the infected plant cell in Fig. $9 . \times 4,000$ 

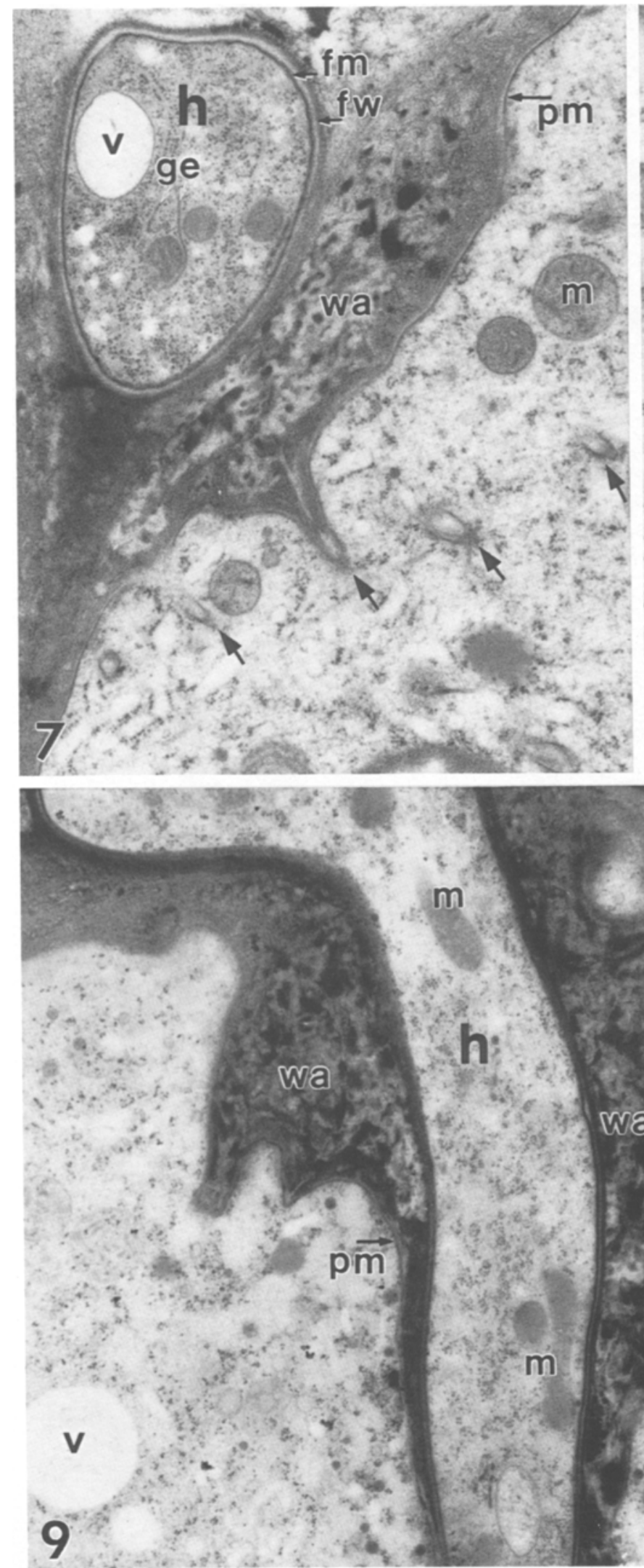

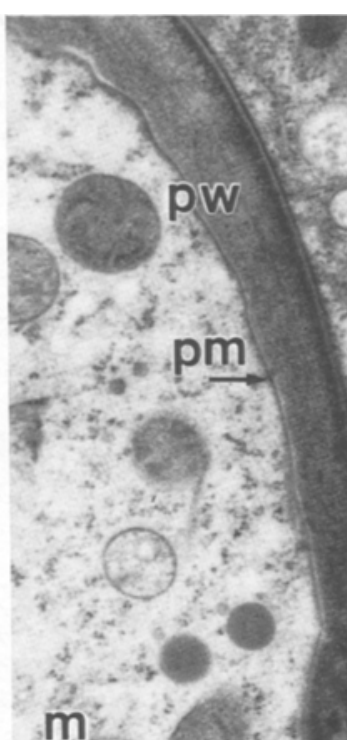

W.

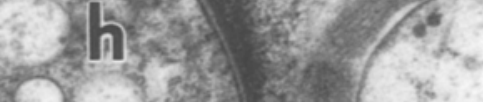

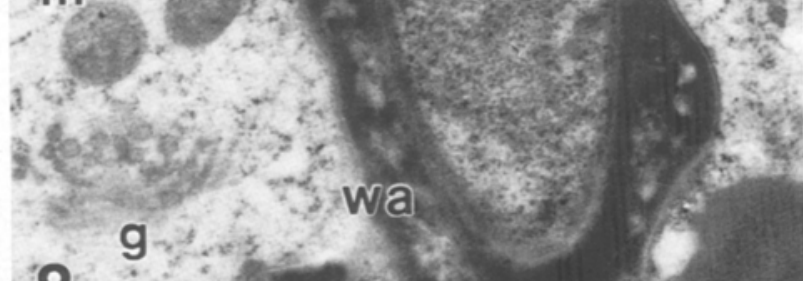

8.20 and
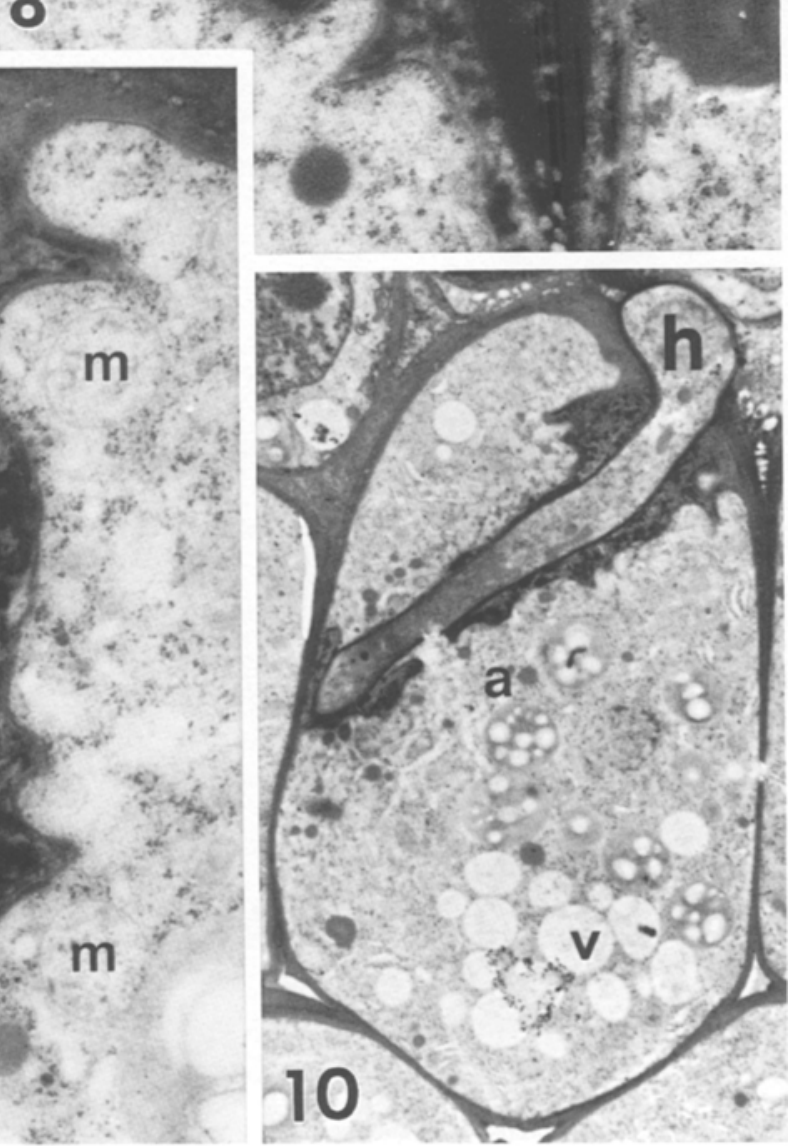


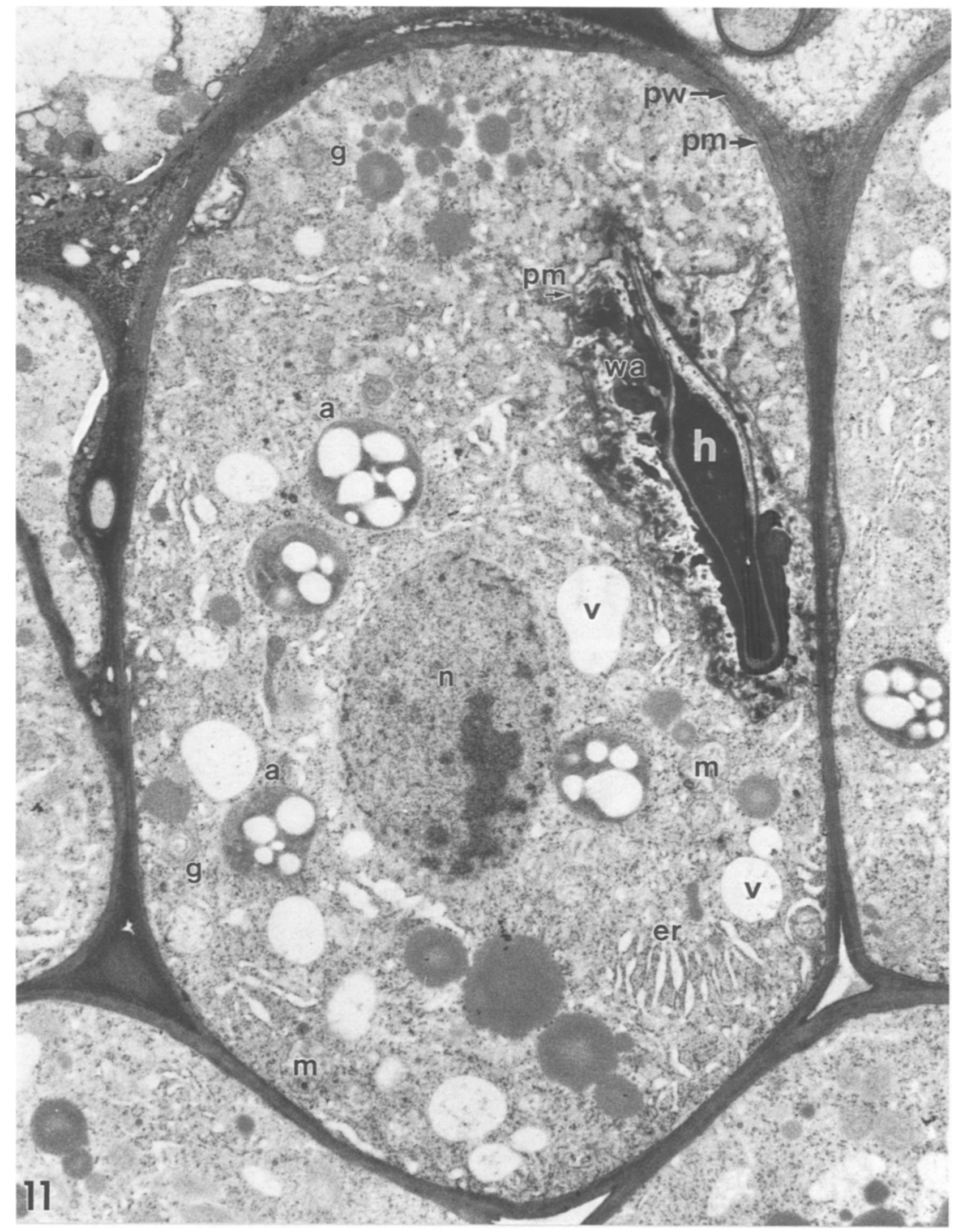

Fig. 11. Protodermal cells in the meristematic zone with an aborted penetration hypha of $F$. oxysporum. a Amyloplast, er endoplasmic reticulum, $g$ Golgi apparatus, $h$ hypha, $m$ mitochondrion, $n$ nucleus, $p m$ plant plasma membrane, $p w$ plant cell wall, $v$ vacuole, wa wall appositions. $\times 11,340$ 
with a width of $30 \pm 1.5 \mathrm{~nm}, 40 \pm 2.9 \mathrm{~nm}$, and $56 \pm 3.9$ nm, respectively (Fig. 5). Contents of cisternae with $40 \mathrm{~nm}$ diameter showed the highest contrast, cisternae with $56 \mathrm{~nm}$ the lowest contrast. We did not find an accumulation of smooth cisternae in a special area of the penetration hypha.

Reaction of the root cell before fungal penetration: Hyphae growing on the root surface regularly induced wall appositions in the plant cell walls below (Fig. 6). Wall appositions between the protodermal wall (for definition see Fahn 1982, Staehelin et al. 1990) and the protoplast stained strongly and contained dark and light inclusions. Finger-like projections of the papilla reached into the cytoplasm of the host cell (Fig. 7). The plasma membrane followed these invaginations smoothly (Fig. 7). No plasmolysis was observed in such cells. Apart from the wall modifications no differences compared to noninfected root tissue were found in the arrangement of plant cells and in the fine structure of organelles in cells contacting the fungus.

Reactions during inter- and intracellular penetration: During intercellular penetration by the fungus wall appositions similar to those described above were produced evenly along the hypha (Fig. 8). Also during intracellular penetration by the fungus, the plant cell reacted in a comparable way. The penetrating hypha was completely surrounded by large amounts of a mixture of electron translucent and electron dense material (Figs. 9 and 10). Apart from these deposits, the penetrated plant cell exhibited no evidence of plasmolysis or damage of cell organelles (Fig. 10). Some penetration hyphae had lost their internal organization, no organelles were discernible, and the cytoplasm stained evenly dark. The surrounding host cells had produced a prominent wall apposition around the apparently dead hyphae, but the cytoplasm including all cell organelles exhibited no damage (Fig. 11).

\section{Elongation zone}

Reaction of the root cell before fungal penetration: Similar to the situation in the meristematic zone, the fungal wall consisted of a fibrillar outer layer and a lightly staining inner layer (Fig. 12). However, in contact with the plant, the inner layer of the fungal wall exhibited small inclusions and the plant cell wall an even, only relatively thin wall apposition with many dark inclusions (Figs. 12 and 13). In contrast to the infected cells in the meristematic zone, no invagi- nations of the wall apposition into the host cytoplasm were observed. In addition, the middle lamella of anticlinal walls of the rhizodermis seemed to split apart in front of the fungal hypha and exhibited a fibrous structure (Fig. 14).

Reaction during inter- and intracellular penetration: Intercellular fungal penetration started where hyphae contacted the middle lamella between the protodermal cells (Fig. 15). From there, penetration of the adjacent plant cells was observed (Fig. 16). Fungal and adjacent plant cell walls exhibited dark inclusions (Figs. 15 and 16). The infected plant cells were not plasmolysed and there was no evidence for alterations of organelles.

Intracellular penetration started without discernible differentiation of an appressorium. At the prospective penetration site, we observed a wall apposition with numerous dark inclusions and finger-like projections reaching out of the apposition into the host cytoplasm (Fig. 17). At the penetration site of the fungus into the epidermal cell the hypha was constricted (Fig. 18). During subsequent fungal penetration into the plant cell the invaginated plant plasma membrane surrounded the hypha smoothly (Fig. 19). The interface of host and parasite consisted of the following layers: the plant plasma membrane, a wall layer with medium staining intensity which was probably of plant origin, a thin layer of higher electron density, possibly corresponding to the fibrillar outer layer of the fungal wall, the electron translucent wall of the fungus with numerous inclusions and the plasma membrane of the fungus (Fig. 20).

\section{Discussion}

\section{Colonization of the root surface}

After germination of conidia and before penetration into the root, F. oxysporum $\mathrm{f}$. sp. vasinfectum formed a compact mycelium on the surface of the cotton roots. Similar observations were made in vitro for other formae specialis of $F$. oxysporum (Brammall and Higgins 1988, Parry and Peg 1985, Smith and Peterson 1983) but also with other soil borne plant pathogens such as Rhizoctonia and Pythium (Huisman and Gerick 1989). This behaviour could be important for the saprotrophic phase of the fungus under natural conditions. In this way the fungus seems to prepare infection sites on the root surface and to compete with nonpathogenic fungi in the soil. Saprotrophic fungi adhere poorly to roots and do not penetrate the rhizodermis (Beswetherick and Bishop 


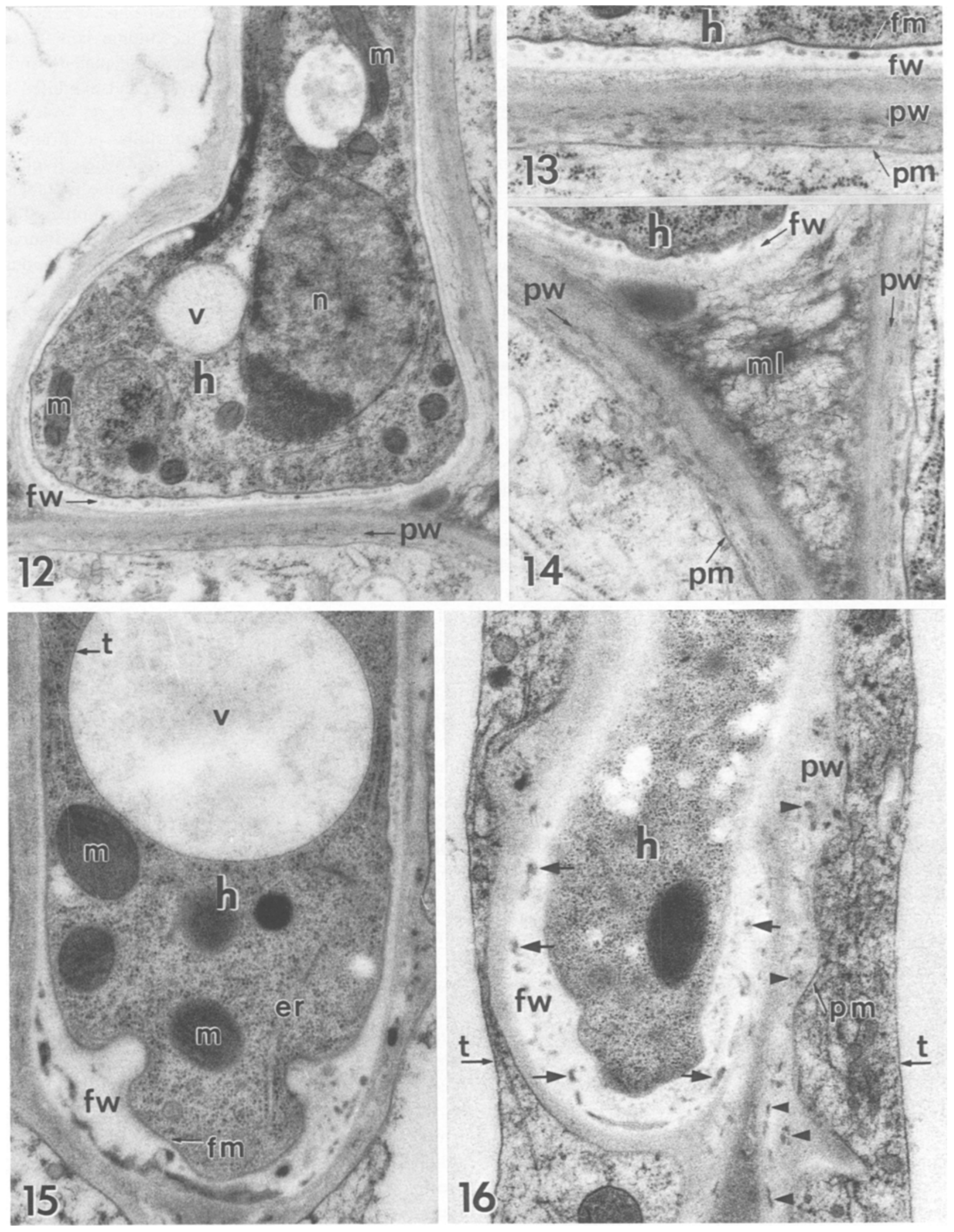


1993). The penetration process of $F$. oxysporum starts with the development of specialized penetration hyphae. This corresponds to the observations made by Bishop and Cooper (1983).

\section{Temperature}

Temperature had a major effect on penetration of Fusarium into cotton roots. The highest frequency of penetration occurred between $28^{\circ} \mathrm{C}$ and $30^{\circ} \mathrm{C}$. This result corresponds to the optimal growth temperature of the fungus in potato-dextrose-agar (data not shown). Similar results have been obtained with other Fusaria producing wilting symptoms. Bhatti and Kraft (1992) found an optimal temperature for disease development by $F$. oxysporum f. sp. pisi and ciceris between $25^{\circ} \mathrm{C}$ and $35^{\circ} \mathrm{C}$, Gardiner et al. (1989) an optimum between $25^{\circ} \mathrm{C}$ and $30^{\circ} \mathrm{C}$ for $F$. oxysporum f. sp. chrysanthemi.

\section{Inoculum concentration}

Previous investigations have reported a direct influence of the inoculum concentration in the soil on the subsequent development of the Fusarium-induced wilt symptoms in different host plants (Elmer and Lacy 1987, Salgado and Schwartz 1993). We found a correlation between the number of conidia used for inoculation of the root tips with the number of penetration hyphae produced by the mycelium. It is interesting to note that, from a statistical point of view, between one and two conidia are needed to produce one penetration hypha. However, a dense surface mycelium must develop before penetration can occur. This dense mycelium did not change the morphology of the root and had no detrimental effect on root development.

\section{Penetration by the fungus in different root zones}

We show for the first time that the meristematic zone of cotton is very important for the early stage of fun- gal infection because the highest number of penetration hyphae developed in this area. Although no quantitative data were provided previously, it has been suggested that the penetration of $F$. oxysporum takes place in the root cap (Alconero 1968), in the meristematic zone (Bishop and Cooper 1983, Gerick and Huisman 1985, Farquhar and Peterson 1989, Smith and Peterson 1983) or in the elongation zone (Bhalla et al. 1992, Jordan et al. 1987). The root secretes exudates. These exudates may influence both germination of conidia and growth of the hyphae (Deacon and Donaldson 1993, Hornby 1990). Since exudates are secreted through the root cap and the meristematic zone and since the concentration decreases with the distance from the root cap (Curl and Truelove 1986, Marschner 1992, Rovira 1969), this gradient might be one reason for the high number of penetration hyphae in the meristematic zone compared to other zones.

In the lateral root zone no penetration of the fungus was found. Since the rhizodermis of the cotton roots contains high concentrations of the terpenoid gossypol in this area (Mace et al. 1974), this might prevent the penetration by the fungus.

\section{Fungal fine structure}

Apart from a few aborted hyphae in the meristematic zone, where plant cells seemed to react more drastically than in the elongation zone during fungal penetration, F. oxysporum exhibited an excellent preservation of the protoplast after high pressure freezing and freeze substitution. Fungal organelles mostly were very similar to those described for $F$. acuminatum grown on cellulose membranes which had been preserved by dip freezing and freeze substitution (Howard 1981). However the Golgi equivalent of $F$. oxysporum, in contrast to the observations by Howard (1981), exhibited some interesting modifications. We observed three populations of smooth cisternae with a considerable difference in electron density of their contents. These three types of cisternae are reminis-

Figs. 12-16. The infection process in the elongation zone. er Endoplasmic reticulum, $f m$ fungal plasma membrane, $f w$ fungal cell wall, $h$ hypha, $m l$ middle lamella, $m$ mitochondrion, $n$ nucleus, $p m$ plant plasma membrane, $p w$ plant cell wall, $t$ tonoplast, $v$ vacuole

Fig. 12. A hypha in contact with a rhizodermal cell. $\times 18,900$

Fig. 13. The interface between the plant cell wall and the fungal cell wall. $\times 40,000$

Fig. 14. The middle lamella below the hypha exhibits a fibrous structure. $\times 40,000$

Fig. 15. An intercellular penetration hypha with invaginations of the fungal plasma membrane and dark inclusions within the fungal cell wall

Fig. 16. Penetration of a hypha into an adjacent plant cell. Note the dark inclusions in the fungal cell wall (arrows) and in the plant cell wall (arrowheads). $\times 27,500$ 


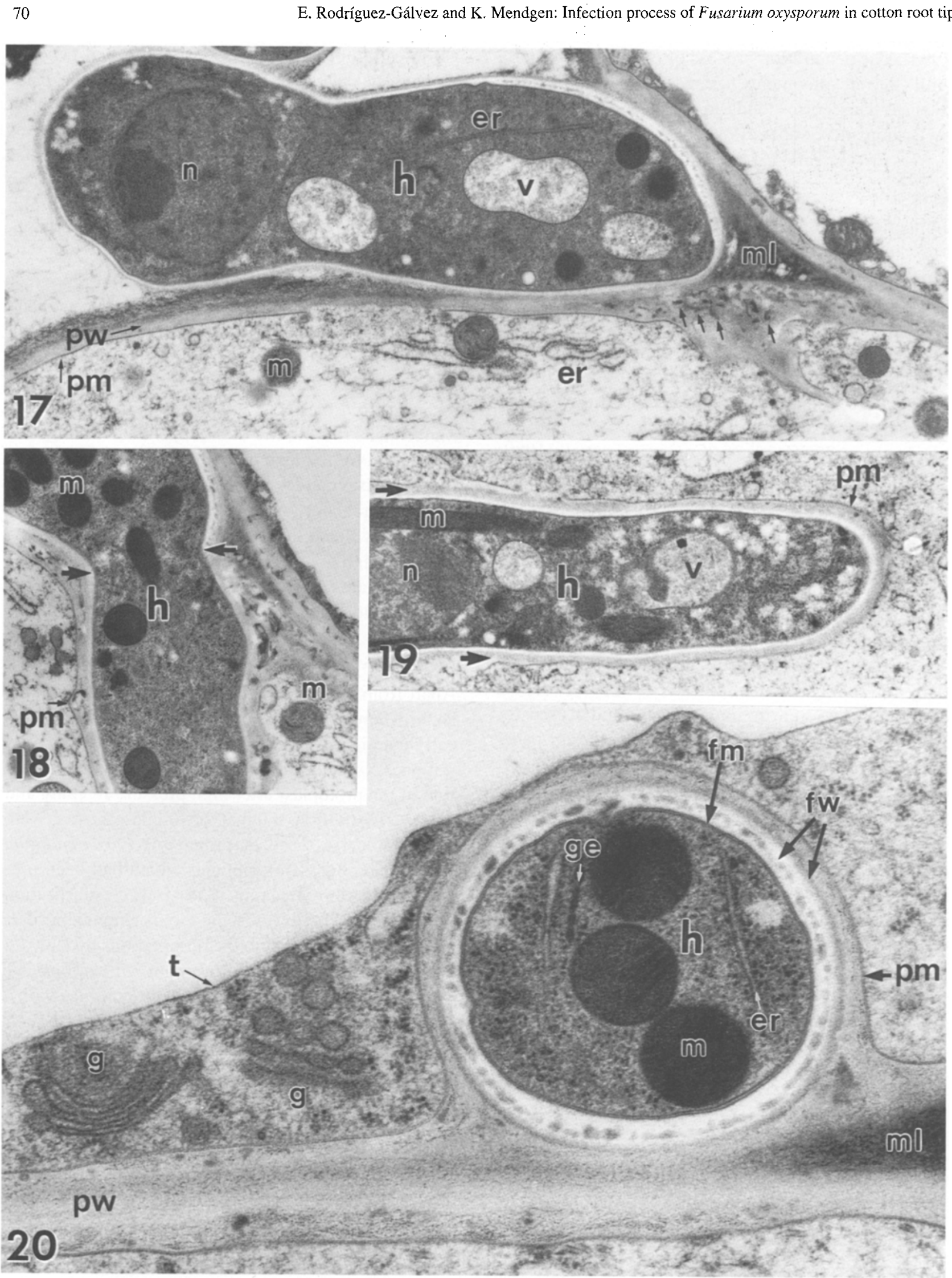


cent of the cis-, medial-, and trans-Golgi subcompartments described for the Golgi in plants and lower fungi (see Mendgen et al. 1995). It would be interesting to compare glycoprotein synthesis in $F$. oxysporum growing on a cellulose membrane and growing within the host plant. Perhaps the secretory activity is much more pronounced or even different in the parasitic phase of the fungus. This would explain the highly elaborated Golgi equivalent in $F$. oxysporum produced during infection.

\section{Cytology of the infected plant cell}

Hyphae growing on the root surface induced the development of wall appositions in both the meristematic and the elongation zone. This indicates an exchange of signals between host and parasite at a very early stage of the interaction. The plant seems to favour fungal growth of root exudates and to induce the formation of penetration hyphae. Formation of penetration hyphae, in turn, induces wall appositions in the plant. Using immuno-electron microscopical techniques, plant cell wall carbohydrates and glycoproteins were detected in these appositions (Rodriguez-Gálvez and Mendgen 1995). However, we did not observe the deposition of vesicles and a convoluted plasma membrane during early stage of papilla formation as reported by Bishop and Cooper (1983). Only by using conventional chemical fixation, we observed vesicles in the area of wall apposition (unpubl. results). Obviously, these latter structures are an artefact of chemical fixation.

Surprisingly in the elongation zone, especially during intracellular growth of Fusarium hyphae with the rhizodermis, the interface between both organisms exhibited similarities with biotrophic (Knauf et al. 1989, Harder and Chong 1990), hemibiotrophic (O'Connell 1987) or mycorrhizal infections (Bonfante-Fasolo et al. 1992). The fungal wall was surrounded by a host matrix with staining properties similar to the normal plant wall. The host plasma mem- brane surrounded this structure evenly and showed no evidence for degradation. It would be interesting to look for a specialization of this membrane similar to the modifications of the extrahaustorial membrane in biotrophic interactions (Knauf et al. 1989).

We could not confirm earlier electron microscopic studies of $F$. oxysporum infection showing host cell necrosis (Smith and Peterson 1983), disintegration of cytoplasm (Brammal and Higgins 1988), or cell death (Bishop and Cooper 1983, Farquhar and Peterson 1983). As indicated by the good condition of the cell membranes and organelles, after high pressure freezing and freeze substitution, the fungus infects living cells. Therefore the term necrotroph (Hardham 1992) for $F$. oxysporum at early stages of the interaction is not appropriate. Recently it has been shown that nonpathogenic isolates of $F$. oxysporum can penetrate and colonize the tissues of carnation and tomato plants without symptom expression (Postma and Rattink 1991, Hallmann and Sikora 1994). These results also indicate that Fusarium can infect plant tissue without inducing major damage. We suggest that the early stages of interaction between cotton root cells and $F$. oxysporum represent a short "endophytic phase" or "biotrophic phase" of the fungus. It is common that pathogenic fungi have a latent phase before causing damage to their host (Fisher and Petrini 1992).

\section{Acknowledgements}

We thank Uli Bachem, Holger Deising, Matthias Hahn, and Martina Stark-Umau for reading the manuscript. The first author is grateful to the Deutsche Akademische Austauschdienst (DAAD) for providing a scholarship.

\section{References}

Alconero R (1968) Infection and development of Fusarium oxysporum f. sp. vanillae in vanilla roots. Phytopathology 58: 1281-1283

Armstrong GM, Armstrong JK (1981) Formae specialis and races of Fusarium oxysporum causing wilt diseases. In: Nelson PE, Tousson TA, Cook RJ (eds) Fusarium: diseases, biology, and taxonomy. The Pennsylvania State University Press, University Park, PA, pp 391-399

Figs. 17-20. Infected rhizodermal cells in the elongation zone. $\mathrm{er}$ Endoplasmic reticulum, $f m$ fungal plasma membrane, $f w$ fungal cell wall, $g$ Golgi apparatus, ge Golgi equivalent, $h$ hypha, $m l$ middle lamella, $m$ mitochondrion, $n$ nucleus, $p m$ plant plasma membrane, $p w$ plant cell wall, t tonoplast, $v$ vacuole

Fig. 17. Beginning of an intracellular penetration of the fungus. The plant cell wall exhibits dark inclusions at the penetration site (arrows). $\times 15,750$

Fig. 18. Constriction of the hypha at the penetration site (arrows). $\times 18,750$

Fig. 19. Clear material around the penetration hypha (arrows). $\times 17,500$

Fig. 20. The hypha is embedded within the host apoplast. Neither organism shows any sign of degeneration. $\times 50,000$ 
Beckman CH (1987) The nature of wilt diseases of plants. American Phytopathological Society, St Paul, MN

Beswetherick JT, Bishop CD (1993) An ultrastructural study of tomato roots inoculated with pathogenic and non-pathogenic necrotrophic fungi and a saprophytic fungus. Plant Pathol 42 : $577-588$

Bhalla MK, Nozzolillo C, Schneider E (1992) Observations on the responses of lentil root cells to hyphae of Fusarium oxysporum. J Phytopathol 135: 335-342

Bhatti MA, Kraft JM (1992) Effects of inoculum density and temperature on root rot and wilt of chickpea. Plant Dis 76: 5054

Bishop CD, Cooper RM (1983) An ultrastructural study of vascular colonization in three vascular wilt diseases. I. Colonization of susceptible cultivars. Physiol Mol Plant Pathol 23: 323 343

Brammall RA, Higgins VJ (1988) A histological comparison of fungal colonization in tomato seedlings susceptible and resistant to Fusarium crown root rot disease. Can J Plant Pathol 66: 915-925

Bonfante-Fasolo P, Peretto R, Perotto S (1992) Cell surface interactions in endomycorrhizal symbiosis. In: Callow JA, Green JA (eds) Perspectives in plant cell recognition. Cambridge University Press, Cambridge, pp 239-255

Curl EA, Truelove B (1986) The rhizosphere. Springer, Berlin Heidelberg New York Tokyo

Deacon JW, Donaldson SP (1993) Molecular recognition in the homing responses of zoosporic fungi, with special reference to Phytium and Phytophthora. Mycol Res 97: 1153-1171

Elmer WH, Lacy ML (1987) Effects of inoculum densities of Fusarium oxysportum $\mathrm{f}$. sp. apii in organic soil on disease expression in celery. Plant Dis 71: 1086-1089

Fahn A (1982) Plant anatomy. Pergamon, Oxford

Farquhar ML, Peterson L (1989) Pathogenesis in Fusarium root rot of primary roots of Pinus resinosa grown in test tubes. Can $\mathrm{J}$ Plant Pathol 11: 221-228

Fisher PJ, Petrini O (1992) Fungal saprobes and pathogens as endophytes of rice (Oryza sativa). New Phytol 120: 137-143

Gardiner DC, Horst RK, Nelson PE (1989) Influence of night temperature on disease development in Fusarium wilt of chrysanthemum. Plant Dis 73: 34-37

Gerick JS, Huisman OC (1985) Mode of colonization of roots by Verticillium and Fusarium. In: Parker CA, Rovira AD, Moore JK, Wong TW, Kollmorgen JS (eds) Ecology and management of soilborne plant pathogens. American Phytopathological Society, St Paul, MN, pp 80-83

Hallman J, Sikora RA (1994) Infiuence of Fusarium oxysporum, a mutualistic fungal endophyte, on Meloidogyne incognita. J Plant Dis Protec 101: 475-481

Harder DE, Chong J (1990) Rust haustoria. In: Mendgen K, Leseman DE (eds) Electron microscopy of plant pathogens. Springer, Berlin Heidelberg New York Tokyo, pp 235-250

Hardham AR (1992) Cell biology of pathogenesis. Annu Rev Plant Physiol Plant Mol Biol 43: 491-526

Hayat MA (1975) Positive staining for electron microscopy. Van Nostrand Rheinhold, New York

Hornby D (1990) Root diseases. In: Lynch JM (eds) The rhizosphere. Wiley, Chichester, pp 233-258

Howard RJ (1981) Ultrastructural analysis of hyphal tip cell growth in fungi: spitzenkörper, cytoskeleton and endomembranes after freeze substitution. J Cell Sci 48: 89-103

Huisman OC, Gerick JS (1989) Dynamics of colonization of plant roots by Verticillium dahiiae and other fungi. In: Tjamos EC, Beckman $\mathrm{CH}$ (eds) Vascular wilt disease of plants. Springer, Berlin Heidelberg New York Tokyo, pp 1-17

Jordan CM, Endo RM, Jordan LS (1987) Penetration and colonization of resistant and susceptible Apium graveolens by Fusarium oxysporum $\mathrm{f}$. sp. apii race 2: callose as a structural response. Can J Bot 66: 2385-2391

Kiss JK, Giddings TH Jr, Staehelin LA, Sack FD (1990) Comparison of the ultrastructure of conventionally fixed and high pressure frozen/freeze substituted root tips of Nicotiana and Arabidopsis. Protoplasma 157: 64-74

Knauf GM, Welter K., Müller M, Mendgen K (1989) The haustorial host-parasite interface in rust-infected bean leaves after highpressure freezing. Physiol Mol Plant Pathol 34: 519-530

Mace ME, Bell AA, Stipanovic RD (1974) Histochemistry and isolation of gossypol and related terpenoids in roots of cotton seedlings. Phytopathology 64: 1297-1302

Marschner $H(1992)$ Nutrient dynamics at the soil-root interface (rhizosphere). In: Read DJ, Lewis DH, Fitter AH, Alexander IJ (eds) Mycorrhizas in ecosystems. CAB International, Wallingford, pp 3-12

Mendgen K, Bachem U, Stark-Urnau M, Xu H (1995) Secretion and endocytosis at the interface of plants and fungi. Can $J$ Bot (in press)

- Welter K, Scheffold F, Knauf-Beiter G (1990) High pressure freezing of rust infected plant leaves. In: Mendgen K, Leseman DE (eds) Electron microscopy of plant pathogens. Springer, Berlin Heidelberg New York Tokyo, pp 31-41

O'Connell RJ (1987) Absence of a specialized interface between intracellular hyphae of Colletotrichum lindemunthianum and cells of Phaseolus vulgaris. New Phytol 107: 725-734

Parry DW, Pegg CF (1985) Surface colonization, penetration and growth of three Fusarium species in lucerne Medicago sativa. Trans Br Mycol Soc 85: 495-500

Postma J, Rattink H (1991) Biological control of Fusarium wilt of carnation with a nonpathogenic isolate of Fusarium oxysporum. Can J Bot 70: 1199-1205

Rodríguez-Gálvez E, Menden K (1995) Cell wall synthesis in cotton roots after infection with Fusarium oxysporum. The deposition of callose, arabinogalactans, xyloglucans, and pectic components into walls, wall appositions, cell plates and plasmodesmata. Planta (in press)

Rovira A (1969) Plant root exudates. Bot Rev 35: 35-57

Salgado MO, Schwartz HF (1993) Physiological specialization and effects of inoculum concentration of Fusarium oxysporum $\mathrm{f}$. sp. phaseoli on common beans. Plant Dis 77: $492-496$

Smith AK, Peterson RL (1983) Examination of primary roots of Asparagus infected by Fusarium. Scann Electron Microsc 3: $1475-1480$

Staehelin LA, Giddings TH, Kiss JZ, Sack FD (1990) Macromolecular differentiation of Golgi stacks in root tips of Arabidopsis and Nicotiana seedlings as visualized in high pressure frozen and freeze-substituted samples. Protoplasma 157: 75-91

Welter K, Müller M, Mendgen K (1988) The hyphae of Uromyces appendiculatus within the leaf tissue after high pressure freezing and freeze substitution. Protoplasma 147: 91-99 